\title{
Analysis of Development Trends of Rosatom and Rostec State Corporations
}

\author{
Nikonova M.A. \\ Institute of Economic Forecasting of the RAS, \\ Central Economics and Mathematics Institute of the RAS, \\ Moscow, Russia \\ flowerchek1982@mail.ru
}

\begin{abstract}
The work is devoted to analysis of indicators of financial economic and productive activities of the Rosatom and Rostec State Corporations. As the analysis results have shown, despite the sanctions against Russia the development of Divisions of the Rosatom GK (according to the dynamics of corresponding indicators) can be assessed positively. It should be noted that today the state corporation is quite dependent on the state support (in the form of budget infusions). In productive performance of the Rostec GK the decline in aviation and shipbuilding industries as well as in industry of conventional weapons, ammunition, and special chemicals was observed. It should be noted also that many problems which are interfering into the State Corporation development are associated with the joining of new companies to it, i.e. they are received "by inheritance".
\end{abstract}

Keywords-main trends of development, State Corporations, Rosatom, Rostec, financial economic indicators, productive performance

\section{ROSATOM STATE CORPORATION}

Indicators of activities of Divisions of Rosatom SC. Mining Division (managing company is Atomredmetzoloto AO (Joint Stock Company)). Main indicators of performance of the Division for the period 2017-2019 are shown in Table 1.

TABLE I. PERformance MAIN Results For THE PERIOD 2015-2019

\begin{tabular}{|l|c|c|c|}
\hline \multicolumn{1}{|c|}{ Performance indicators } & $\mathbf{2 0 1 7}$ & $\mathbf{2 0 1 8}$ & $\mathbf{2 0 1 9}$ \\
\hline Mineral resource base, thousand tons & 523,9 & 520,7 & 512,7 \\
\hline Uranium production, tons, total & 2917 & 2904 & 2911 \\
\hline Average headcount, people & 6657 & 7232 & 7153 \\
\hline \multicolumn{4}{|l}{ a. } \\
\hline
\end{tabular}

Fig. 1 shows the dynamics of mineral resource base (20172019).

Of 01.01.2020 the Uranium Mineral Resource Base (MRB) of the Division amounted to 512.7 thousand tons. By its volume the MRB occupies the second place among the largest uranium mining world companies. The MRB decreased due to the annual redemption of balance reserves during uranium mining in the amount of 3.4 thousand tons of

\author{
Akinfeeva E.V. \\ Institute of Economic Forecasting of the RAS, \\ Central Economics and Mathematics Institute of the RAS, \\ Moscow, Russia, \\ tyusha08@gmail.com
}

uranium, as well as due to the voluntary refusal of UDC Gornoe AO from licenses for the right to use subsoil at the Gornoe and Berezovoe deposits with total reserves of 4.6 thousand tons uranium for economic reasons.

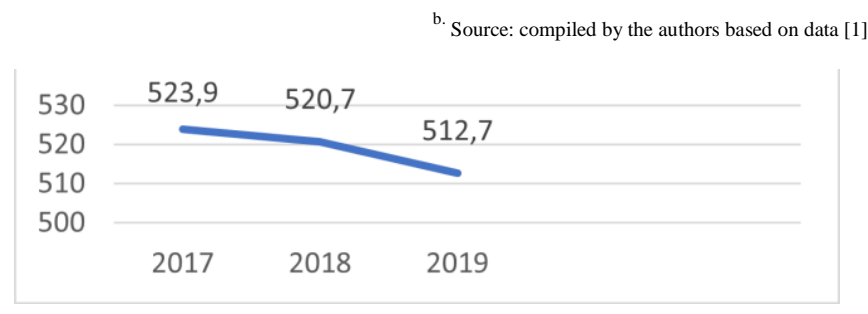

Fig. 1. Indicators of mineral resource base for the period 2017-2019

Uranium production for the period 2017-2019 is shown in Fig. 2.

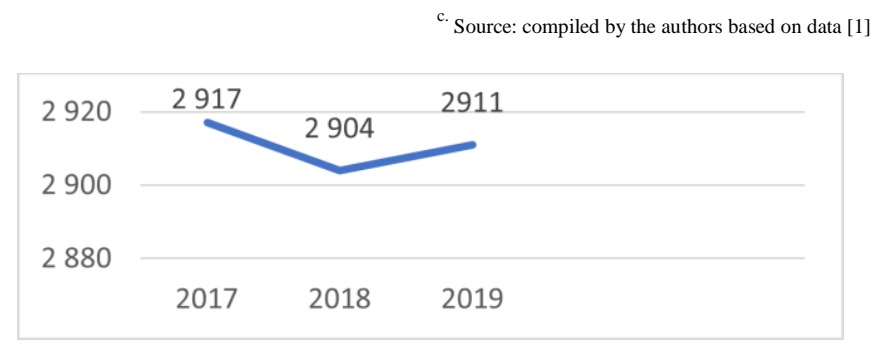

Fig. 2. Dynamics of uranium production for the period 2017-2019

The performance results of enterprises of the Division for the period 2017-2019 are shown in Table 2.

TABLE II. PRODUCTIVE PERFORMANCE OF ENTERPRISES FOR THE PERIOD 2017-2019

\begin{tabular}{|l|l|c|c|c|}
\hline \multicolumn{1}{|c|}{ Enterprises } & Performance indicators & $\mathbf{2 0 1 7}$ & $\mathbf{2 0 1 8}$ & $\mathbf{2 0 1 9}$ \\
\hline $\begin{array}{l}\text { PPGHO PAO } \\
\text { (Public Joint }\end{array}$ & $\begin{array}{l}\text { Uranium production } \\
\text { volume, tons }\end{array}$ & 1631 & 1456 & 1300 \\
\cline { 2 - 5 } Stock Company) & Uranium reserves, tons & 100.8 & 99.2 & 97.9 \\
\hline Hiagda AO & $\begin{array}{l}\text { Uranium production } \\
\text { volume, tons }\end{array}$ & 694 & 858 & 1016 \\
\cline { 2 - 5 } & Uranium reserves, tons & 37.1 & 36,1 & 34.8 \\
\hline
\end{tabular}




\begin{tabular}{|l|l|c|c|c|}
\hline Dalur AO & $\begin{array}{l}\text { Uranium production } \\
\text { volume, tons }\end{array}$ & 592 & 590 & 595 \\
\cline { 2 - 5 } & Uranium reserves, tons & 14,8 & 14.2 & 13.4 \\
\cline { 2 - 5 } & $\begin{array}{l}\text { Coal production, million } \\
\text { tons }\end{array}$ & 3.31 & 3.03 & - \\
\hline \multicolumn{4}{|c}{ d. Source: compiled by the authors based on data [1] }
\end{tabular}

Fig. 3 shows the dynamics of growth (decline) in the volume of uranium production (in tons) and the amount of uranium reserves (in tons) for three main enterprises of the Division.

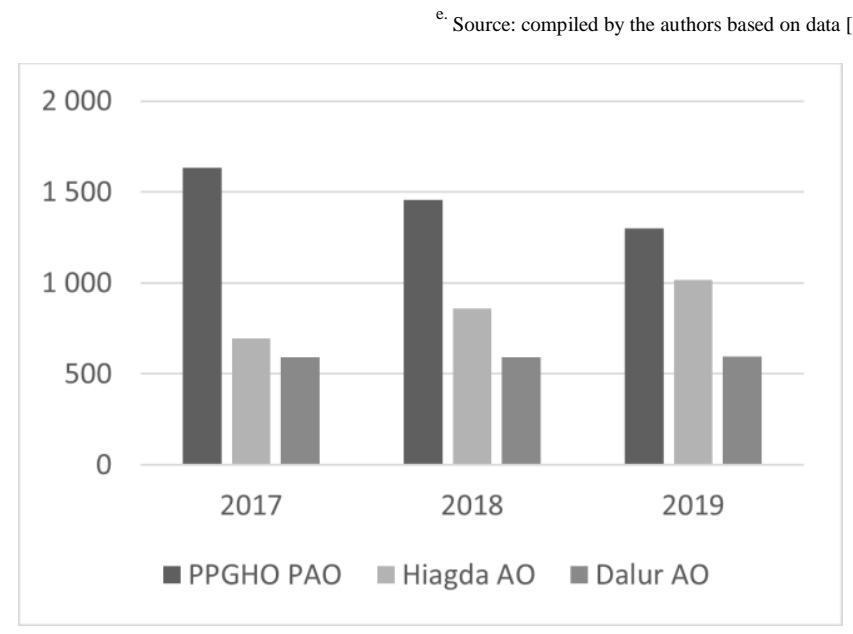

Fig. 3. Production volume and uranium reserves of enterprises for the period 2017-2019

In 2017-2019, in the Division there is a decrease in underground uranium mining and an increase in downhole underground leaching production.

Fuel Division (the Managing Company is TVEL AO). Main performance indicators of the Division for 2017-2019 are shown in Tables 3, 4 .

TABLE III. PERFORMANCE MAIN RESULTS

\begin{tabular}{|l|c|c|c|}
\hline \multicolumn{1}{|c|}{ Performance indicators } & $\mathbf{2 0 1 7}$ & $\mathbf{2 0 1 8}$ & $\mathbf{2 0 1 9}$ \\
\hline Consolidated revenue, RUB million & 180683 & 163173 & 194619 \\
\hline Average headcount, people & 21793 & 22451 & 22111 \\
\hline R\&D investments, RUB million & 1195 & 1540 & 1839 \\
\hline \multicolumn{4}{|l}{ f. Source: compiled by the authors based on data [2] }
\end{tabular}

The Division includes: separation and sublimation complex $(R S K)$ - conversion and enrichment of uranium (enterprises for the fabrication of nuclear fuel (YaT), conversion and enrichment of uranium) - SHK AO, AEHK AO, PO EHZ AO, UEHK AO; nuclear fuel fabrication complex (KFYaT) - creation of fuel assemblies (TVS) for nuclear reactors - MSZ PAO, NZHK PAO, ChMZ AO, MEP $\mathrm{AO}$; gas centrifuge complex (GTsK) - manufacture of gas centrifuges and auxiliary equipment (manufacture of gas centrifuges)- KMZ PAO; Tsentroteh NPO (Research and Production Association) OOO (Limited Liability Company); research complex - VNIINM AO; TsPTI; Tochmash VPO. It should be noted that, unfortunately, there is no publicly available data for 2019 , so it is not possible to carry out any analysis.
As Table 4 shows, labor productivity of the enterprises of separation and sublimation complex (RSK) is not uniform. It decreases in 2018 relative to 2017 by $3 \%$ in SHK AO, by $7 \%$ in UEHK $\mathrm{AO}$, in UEHK $\mathrm{AO}$ it was 4\%. In $\mathrm{AEHK} \mathrm{AO}$ Company the labor productivity increased by $8 \%$. Unfortunately, in the annual report for 2019 there are no data on the Division companies.

TABLE IV. PRODUCTION PERFORMANCE RESUlTs

\begin{tabular}{|c|c|c|c|}
\hline Complex & $\begin{array}{c}\text { Main enterprises - labor } \\
\text { productivity, million rubles / } \\
\text { person }\end{array}$ & 2017 & 2018 \\
\hline \multirow{4}{*}{$\begin{array}{l}\text { Separation and } \\
\text { sublimation complex } \\
(\mathrm{RSK})\end{array}$} & SHK AO & 5.17 & 5.01 \\
\hline & AEHK AO & 7.04 & 7.61 \\
\hline & EHZ PO AO & 7.41 & 7.73 \\
\hline & UEHK AO & 11.18 & 10.40 \\
\hline \multirow{4}{*}{$\begin{array}{l}\text { Complex for fabrication } \\
\text { of nuclear fuel (KFYaT) }\end{array}$} & MSZ PAO & 5.33 & 4.38 \\
\hline & NZHK PAO & 6.04 & 6.04 \\
\hline & ChMZ AO & 4.38 & 4.56 \\
\hline & MEP AO & 4.48 & 1.20 \\
\hline \multirow{2}{*}{$\begin{array}{l}\text { Gas centrifuge complex } \\
\text { (GTsK) }\end{array}$} & KMZ PAO & 2.79 & 3.41 \\
\hline & Tsentroteh NPO OOO & 2.06 & 2.52 \\
\hline \multirow[t]{3}{*}{ Research complex } & VNIINM AO & 2.13 & 2.92 \\
\hline & TsTI AO & 1.66 & 1.67 \\
\hline & Tochmash VPO AO & 1.56 & 2.19 \\
\hline
\end{tabular}

Mechanical Engineering Division (the Managing Company is Atomenergomash AO). Main performance indicators of the Division for 2017-2019 are shown in Table 5.

TABLE V. MAIN PERFORMANCE RESUlts of THE Division AS A WhOLE

\begin{tabular}{|l|c|c|c|}
\hline \multicolumn{1}{|c|}{ Performance indicators } & $\mathbf{2 0 1 7}$ & $\mathbf{2 0 1 8}$ & $\mathbf{2 0 1 9}$ \\
\hline Consolidated revenue, RUB bln & 68 & 71 & 75 \\
\hline Average headcount, people & 15998.7 & 16064.2 & 16732.5 \\
\hline $\begin{array}{l}\text { Shipment of engineering products, } \\
\text { number of NPPs }\end{array}$ & 11 & 6 & 9 \\
\hline $\begin{array}{l}\text { Share in the Russian EMS } \\
\text { (electromagnetic compatibility) industry } \\
\text { by revenue, \% }\end{array}$ & $27 . .9$ & 33.9 & 37.9 \\
\hline
\end{tabular}

Fig. 4 presents the dynamics of consolidated revenue of the Division for 2017-2019.

${ }^{\text {i. }}$ Source: compiled by the authors based on data [3]

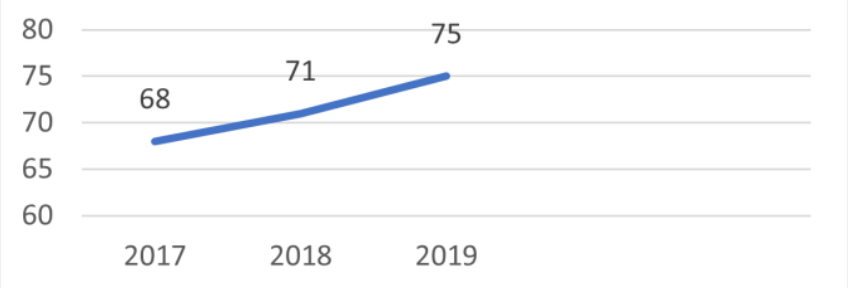

Fig. 4. Dynamics of consolidated revenue of the Division for the period 2017-2019

As Fig. 4 shows, the consolidated revenues of the companies for the considered period are gradually growing. Fig. 5 shows the sector structure of the Division's order book for the period 2017-2019. 
At the end of 2019, the Division's order book for a 10-year period exceeded RUB 756 billion, the revenue exceeded RUB 75 billion [3]

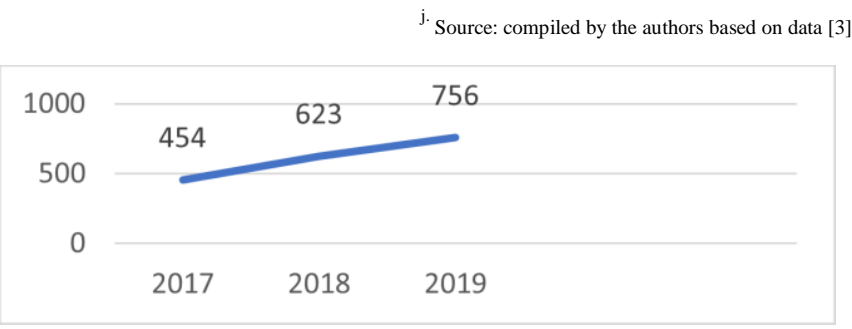

Fig. 5. Growth dynamics of sector structure of the Division's order book (2017-2019)

Electric Power Division (the Managing Company is Kontsern Rosenergoatom AO). Main performance indicators of the Division for 2017-2019 are shown in Tables 6, 7.

TABLE VI. MAIN PERFORMANCE RESULTS

\begin{tabular}{|l|c|c|c|}
\hline \multicolumn{1}{|c|}{ Performance indicators } & $\mathbf{2 0 1 7}$ & $\mathbf{2 0 1 8}$ & $\mathbf{2 0 1 9}$ \\
\hline Consolidated revenue, RUB mln & 418871 & 466622 & 546851 \\
\hline Average headcount, people & 48433 & 48860 & 54412 \\
\hline NPP electricity generation, billion kWh & 202.868 & 204.274 & 208.785 \\
\hline \multicolumn{4}{|c}{ k. Source: compiled by the authors based on data [4] }
\end{tabular}

TABLE VII. PRODUCTIVE PERFORMANCE RESUlTS

\begin{tabular}{|l|c|c|c|}
\hline \multicolumn{1}{|c|}{ Performance indicators } & $\mathbf{2 0 1 7}$ & $\mathbf{2 0 1 8}$ & $\mathbf{2 0 1 9}$ \\
\hline Electricity generation, billion kWh & 202.9 & 204.3 & 208.8 \\
\hline Power units in operation (in RF) & 35 & 37 & 36 \\
\hline Number of power units put into operation & 1 & 2 & 1 \\
\hline $\begin{array}{l}\text { Number of power units under construction } \\
\text { in the Russian Federation }\end{array}$ & 9 & 9 & 5 \\
\hline
\end{tabular}

${ }^{1}$ Source: compiled by the authors based on data [4]

Fig. 6 shows the growth dynamics of electricity generation for the period 2017-2019.

${ }^{\mathrm{m}}$. Source: compiled by the authors based on data [6]

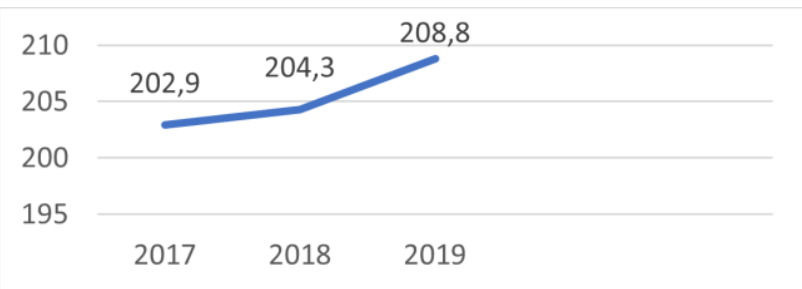

Fig. 6. Growth dynamics of electricity generation (2017-2019)

In general, the production activities of the Corporation's Divisions should be assessed as positive, despite the sanctions that were imposed against Russia.

\section{ROSTEC STATE CORPORATION}

Analysis of the dynamics (growth rates) of the main indicators of the State Corporation for 2016-2019 (2015 = $100 \%$ ), as well as financial and production indicators of individual subsectors (aviation industry, shipbuilding and conventional weapons industry)
The Corporation indicators for the period 2015-2018 are shown in table 8 .

TABLE VIII. DYNAMICS OF THE MAIN INDICATORS OF ROSTEC GK $(2016-2018)(2015=100 \%)$

\begin{tabular}{|l|c|c|c|c|}
\hline \multicolumn{1}{|c|}{ Indicator } & $\mathbf{2 0 1 6}$ & $\mathbf{2 0 1 7}$ & $\mathbf{2 0 1 8}$ & $\mathbf{2 0 1 9}$ \\
\hline Consolidated net income (loss) & 88.9 & 137.8 & 105.6 & 139.9 \\
\hline Consolidated revenue & 111.1 & 125.5 & 103.4 & 107.8 \\
\hline Production per employee & 102 & 112.9 & 103.4 & 96.7 \\
\hline Average salary & 107.6 & 105.9 & 106.0 & 109.9 \\
\hline Share of civilian products in revenue & 96.5 & 114.7 & 105.2 & 102.6 \\
\hline
\end{tabular}

Results of the analysis of the data in Table 8 show that in 2016 there was a significant decrease in consolidated net income. Subsequent growth (2017-2019) was not uniform: in 2017 and 2019 the growth was about $40 \%$, in 2018 it was $5.6 \%$, this indicating the uneven development of the State Corporation. At the same time, the consolidated revenue grew during the entire considered period. However, in the last considered 2 years (2018 and 2019) the growth rate of the indicator decreased (to $103.4 \%$ and $107.8 \%$, respectively).

In 2016-2018 the growth rate of the production per employee increased (on average by $6 \%$ annually). However, in 2019 there was a decline in the indicator (by 3.3\%). The growth rate of the average salary was also relatively constant (on average by $7 \%$ annually). Against the background of the indicated changes there is a growth in the number of employees in the State Corporation (in 2019 it was 590.6 thousand people, the growth rate was $11.6 \%$ in relation to 2018).

It should be especially noted that the State Corporation is gradually increasing the share of civilian products in revenue (beginning from 2017). But the growth rates are not yet very high (in 2018 they were $105.2 \%$ in relation to 2017, in 2019 they were $102.6 \%$ in relation to 2018 ).

Next, we will focus on the analysis of the dynamics of performance indicators of main branches of the Corporation which looks as follows.

Aviation industry. In 2018 there was a significant decline in production in relation to 2017 (by 12.7\%). It should be noted that the decrease in production (both for domestic and foreign markets) resulted in the decrease in production in general. So, in 2019 the decline in production in the domestic market was $9.1 \%$ in relation to 2018 (at the same time, in 2018 the decline was $10.4 \%$ in relation to 2017), the decline in the foreign market was $0.2 \%$ (however, in 2018 the decline was $16.4 \%$ in relation to 2017). In 2019 the decline in production volumes continued (by $5.8 \%$ ). This led to the fact that in 2019 there was a decrease in revenue by $2 \%$ in relation to 2018 .

At the same time, the drop in production volumes in the industry under consideration was characteristic also of the production for needs of OPK (Defense Industrial Complex). The significant drop in the indicator in 2018 (by 17\%) completely "blocked" its growth in 2015-2017 (when it was 6-8\% annually). The drop continued also in 2019 (in relation to 2018 it was $0.3 \%$ ).

Also, there is a decrease in the production of civilian products of the branch (in 2015 it was $9.2 \%$ in relation to 
2014). In 2017-2018, the production growth of $1-4 \%$ could not change the situation. In addition, in 2019 there was a significant drop of the production of civilian products in the aviation industry which was $20.2 \%$ in relation to 2018 (Fig. 7).

${ }^{\text {o. }}$ Source: built by the authors base on data [9]

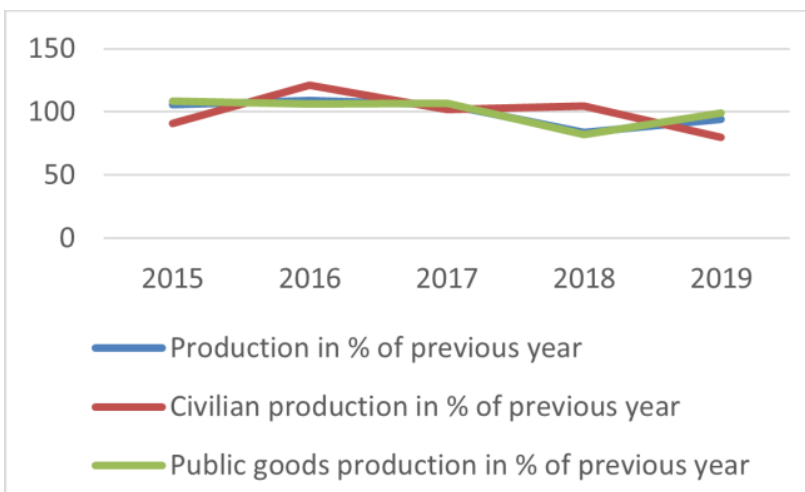

Fig. 7. Industrial economic performance indicators of enterprises (organizations) of aviation industry in Russia in 2015-2019

In 2018 the main branches of the aviation industry were aircraft manufacturing (about 30\% of production volumes), helicopter manufacturing and aircraft engine building (about 20\%). It should be noted that in 2019 there was a slight change in the structure of the aviation industry. Thus, the largest share belonged to aircraft engine building (26.9\%) and aircraft manufacturing $(26.7 \%)$. This is followed by helicopter construction $(16.7 \%)$ and production of special equipment $(10.2 \%)$. The indicated change in the production structure of the aviation industry was due to the growth in the production rate of special equipment in 2019 (by 28.6\%) and aircraft engine building (by 3.8\%). At the same time, in all other subsectors of the aviation industry, there was a decrease in production rates: in helicopter manufacturing - by $11.9 \%$, aircraft manufacturing - by $17.6 \%$, aircraft engineering - by $11.6 \%$, aircraft instrument manufacturing - by $13.2 \%$.

Shipbuilding. The paper analyzes the results of the shipbuilding industry for 2015-2018. During this period, there was a decrease in the production of civil ships and boats by almost 2 times (or by 41 units). It can be noted that the decline in 2016 and 2018 was approximately the same -22 units and 18 units, respectively [10-12].

As for the export indicators of the shipbuilding industry products, we can note that in 2015-2017 they practically did not change. However, civil products export and export through the military technical collaboration (VTS) varied unevenly. So, in the period under review there occurred an insignificant increase in export volumes through the VTS which is more than $90 \%$ of all exports of the shipbuilding industry. Against the background of the export growth of products through the VTS there occurred a decrease in the civilian products export [10-12].

In 2016-2018 the expansion of the domestic market of the shipbuilding industry was observed. However, in 2017-2018 the growth rates were lower than in 2016. At the same time, the production volumes did not increase. If they practically did not change in terms of state orders (in 2018 they were RUB
294.5 billion), the volume of civilian production for the domestic market decreased.

The structure of shipbuilding production is shown in Fig. 8.

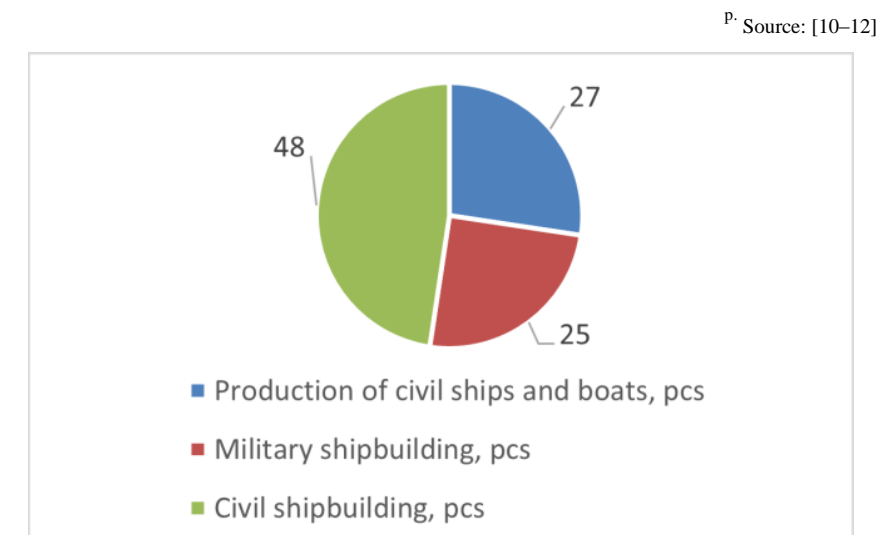

Fig. 8. Shipbuilding production structure of Rostec GK in 2018, \%

Industry of conventional weapons, ammunition and special chemicals. The paper analyzes the changes in the technical and economic indicators of the industry of conventional weapons, ammunition and special chemicals for the period 2016-2018 (Fig. 9).

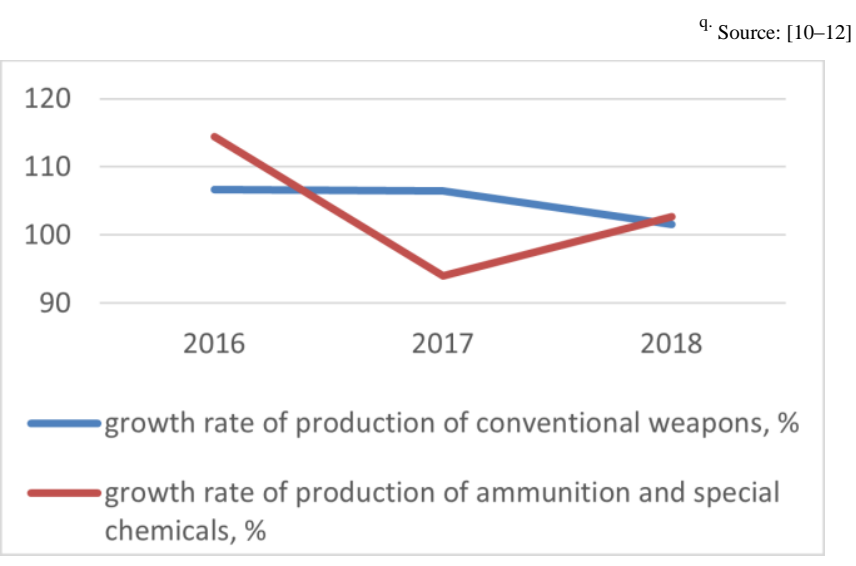

Fig. 9. Technical and economic indicators of industry of conventional weapons in 2016-2018, \%

As can be seen from the data in Fig. 9, during the period under review, the development of industrial production of conventional weapons was observed, but the growth rate of this sub-industry did not exceed 7\%. Moreover, in 2018 there was a decrease in the growth rates of the type of industry under consideration to $1.6 \%$.

The analysis of the dynamics of growth rates of the industrial production of ammunition and special chemicals showed that in 2016 there had been a growth in this subsector by $14.4 \%$. However, in 2017 there was a drop in the indicated parameter (by 6\%). The increase in the indicator under consideration (by 2.7\%) which occurred in 2018 could not exceed its drop in 2017 , i.e. the level of the growth rates of the industrial production of ammunition and special chemicals in 2018 could not reach the level of 2016. 


\section{CONCLUSION}

So, the analysis of main industrial branches included into the Rostec State Corporation allows us to note an extremely negative trend: the production drop which was observed in the branches under consideration in the period from 2015 to 2019. Thus, in the aviation industry it started in 2016 when there observed a decrease in the growth rates, and aggravated by 2019. Also, the decrease in production volumes was observed in the shipbuilding industry (especially in the civilian production). In the development of the industry of conventional weapons, ammunition and special chemicals there also observed a negative trend, this being especially true for the industry of ammunition and special chemicals.

The development of the Rostec State Corporation so far is mainly due to the subsectors related to OPK (Defense Industrial Complex) (this concerns both production for domestic use and export). Despite the growth of individual indicators in 20152016, in the recent few years their decrease has been observed which affects not only the development of corresponding branches, but threatens the development of the State Corporation as well as the aviation industry, shipbuilding, weapons industry, this fact is sure to affect the development of Russian economy and its competitiveness in the world markets. One of the ways to improve the situation may be to change the structure of the State Corporation (towards optimization of noncore assets, especially those that increase the debt burden). However, it should be remembered that the development of the State Corporation, to the authors' mind, cannot be reduced only to the abandonment of unprofitable assets as in future this could lead to catastrophic results.

\section{REFERENCES}

[1] Atomredmetzoloto JSC. (In Russ.). Retrieved from http://www.armz.ru/

[2] TVEL JSC. (In Russ.). Retrieved from http://www.tvel.ru/

[3] Atomenergomash JSC. (In Russ.). Retrieved from https://www.aemgroup.ru.ru/

[4] Rosenergoatom Kontsern JSC. (In Russ.). Retrieved from https://www.rosenergoatom.ru/

[5] Annual Report 2016 of the State Corporation "Rostec". (In Russ.). Retrieved from https://www.behance.net/gallery/54879129/AnnualReport-2016-of-the-State-Corporation-Rostec

[6] Annual Report 2017 of the State Corporation "Rostec". (In Russ.). Retrieved from https://raex-a.ru/annual_reports/reports/2017_rosteh.pdf

[7] Consolidated revenue of Rostec from 2009 to 2019. (In Russ.). Retrieved from https://www.statista.com/statistics/692893/rostecannual-revenues/

[8] Annual report of the ROSTEC State Corporation for 2019. (In Russ.) Retrieved from https://rostec.ru/upload/iblock/3bd/3bd6c2b566d316beb5a14e5b591169 b8.pdf

[9] Aviation industry [Aviaprom]. Annual report for 2019. (In Russ.) Retrieved from http://www.aviaprom.pro/jdownloads/2020/godotch-aoaviaprom-za-2019-god-1.pdf

[10] Report on the goals and objectives of the Ministry of Industry and Trade of Russia for 2017 and the main performance results for 2016 [Doklad o tselyakh i zadachakh Minpromtorga Rossii na 2017 god i osnovnykh resul'tatakh deyatel'nosti za 2016 god]. (In Russ.). Retrieved from http://minpromtorg.gov.ru/common/upload/files/Minpromtorg_blok_15. 03_final_for_web.pdf

[11] Report on the goals and objectives of the Ministry of Industry and Trade of Russia for 2018 and the main performance results for 2017 [Doklad o tselyakh i zadachakh Minpromtorga Rossii na 2018 god i osnovnykh resul'tatakh deyatel'nosti za 2017 god]. (In Russ.). Retrieved from http://minpromtorg.gov.ru/common/upload/docVersions/5ad48d069014f /actual/Minpromtorg_press2.pdf

[12] Report on the goals and objectives of the Ministry of Industry and Trade of Russia for 2019 and the main performance results for 2018 [Doklad o tselyakh i zadachakh Minpromtorga Rossii na 2019 god i osnovnykh resul'tatakh deyatel'nosti za 2018 god] (In Russ.). Retrieved from http://www.spzoo.ru/engine/doc_images/Minprom_maket_main_r05.pdf 